\title{
Effective Detection, Isolation and Characterization of Dakaramine from Ghanaian Axinella sp and Bioactivity
}

Keywords: lodotyramine; Acetamide; Bioaccumulation; J urkat cells; HL60 cells; Cytotoxic ity; ICPMS/ESMS

\begin{abstract}
The Ghanaian sponge Axinella sp collected for the first time from the Gulf of Guinea yielded similar amounts of dakaramine (1) acetamide and a new hydroxylated acetate metabolite (2). The structures of these metabolites were elucidated by $1 D$ and 2D NMR data interpretation. The halogens in dakaramine were detected by high perfomance liquid chromatography coupled with inductively coupled plasma and electrospray ionization mass spectrometry (HPLC-ICPMS/ESMS), a technique that allows for heteroatoms and metals in organic compounds to be detected specifically and with very high sensitivity. Cytotoxic ity of dakaramine was assessed in vitro using two human cancer cell lines, human lymphocytic cell (J urkat) and acute promyelocytic leukemia (HL60). This compound was found to be acutely toxic to these cell lines with IC 50 values of 35.0 and 26.5 $\mu \mathrm{g} / \mathrm{ml}$ respectively.
\end{abstract}

\section{Introduction}

Documentation of marine secondary metabolites with interesting and useful biological activities is mainly focused on source organisms, characteristic chemistry and activity [1]. While some metabolites are a characteristic of some taxa at the level of phylum, class, order, family, genus or even species, many other marine metabolites have been isolated across Phyla [1]. Iodotyramine derivatives are a good example of marine secondary metabolites with interesting activity that have been isolated across different Phyla including Porifera [2,3], Mollusca [4,5] and Chordata [6]. The continued isolation of iodotyramine derivatives from different marine organisms offers direct attestation of their importance. These metabolites are known to function as cross-kingdom signalling molecules, regulators of development, growth or differentiation and metabolism [7]. The first iodotyramine derivative to come from marine sources is 2,5-diiodotyrosine, isolated from the octocoral Gorgonia cavolii [8]. Since then iodotyramine derivatives have been reported from a number of genera of tunicates, for example Didemnum [6] and Aplidium [9]. Sponges like Ptilocaulis [3] and Iotrochota [2] alongside molluscs, for example Turbo $[4,5]$ have also been reported as sources of iodotyramine derivatives. Detailed structure activity investigations for the turbotoxins showed acute toxicity due to their resemblance to acetyl choline and ability to inhibit acetyl cholinesterase [4,5].

We report herein the chemical characterization of a Ghanaian Axinella sp collected for the first time from the Gulf of Guinea. The structure of the known dakaramine was elucidated by a combination of $1 \mathrm{D}$ and 2D NMR spectra together with HPLC ICPMS/ESMS techniques. Dakaramine was found to occur in the crude extracts as a

\section{Journal of Chemistry \& Applications}

Kwaku Kyeremeh ${ }^{1 \star}$, Kojo Sekyi Acquah ${ }^{1}$, Regina Appiah-Opong $^{2}$, Hai Deng ${ }^{3}$ and Marcel Jaspars ${ }^{3}$

${ }^{1}$ Marine and Plant Research Laboratory of Ghana, Department of Chemistry, University of Ghana, Box LG 56, Ghana

${ }^{2}$ Department of Clinical Pathology, Noguchi Memorial Institute for Medical Research, University of Ghana, Box LG 581, Ghana

${ }^{3}$ Marine Biodiscovery Centre, Department of Chemistry, University of Aberdeen, Old Aberdeen, AB24 3UE, Scotland, UK

Address for Correspondence

Dr. Kwaku Kyeremeh, Marine and Plant Research Laboratory of Ghana, Department of Chemistry, University of Ghana, Box LG 56, Ghana, Tel: +233207891320; E-mail: kkyeremeh@ug.edu.gh

Copyright: (๑) 2014 Kyeremeh K, et al. This is an open access article distributed under the Creative Commons Attribution License, which permits unrestricted use, distribution, and reproduction in any medium, provided the original work is properly cited.

Submission: 25 March 2014

Accepted: 18 August 2014

Published: 25 August 2014

mixture with almost equal amounts of acetamide and a hydroxylated acetate metabolite. We tested Dakaramine for the first time against human lymphocytic cell (Jurkat) and acute promyelocytic leukemia (HL60) cell lines in vitro and found it to be acutely toxic to these cell lines, which is completely in line with activity studies conducted previously for some derivatives of Dakaramine including the turbotoxins. The Axinella sp was identified by Professor Robert van Soest at the Zoological Museum of the University of Amsterdam. A voucher specimen (ZMAPOR22540) is deposited at the museum in Amsterdam.

\section{Materials and Methods}

\section{Invertebrate material}

The sponge material, Axinella sp was collected off the East coast of Ghana near Prampram in Tema-Accra at about $10 \mathrm{~m}$ depth. This represents the first report of Axinella sp from the Gulf of Guinea. A voucher specimen (ZMAPOR22540) is deposited at the museum in Amsterdam.

\section{Extraction and isolation}

Invertebrate sample (565 g) was extracted repeatedly with $\mathrm{CH}_{3} \mathrm{OH}$ and $\mathrm{CH}_{2} \mathrm{Cl}_{2}$. Both $\mathrm{CH}_{3} \mathrm{OH}$ and $\mathrm{CH}_{2} \mathrm{Cl}_{2}$ fractions were combined, dried under vacuum ( $3.3 \mathrm{~g})$ and suspended in $\mathrm{H}_{2} \mathrm{O}(250$ $\mathrm{ml}$ ). The $\mathrm{H}_{2} \mathrm{O}$ suspension was then extracted three times with $250 \mathrm{ml}$ $\mathrm{CH}_{2} \mathrm{Cl}_{2}$ and the resulting fraction was evaporated under vacuum to give a total organic extract $(1.1 \mathrm{~g})$. The organic extract was subjected to further solvent partition to give hexane ( $96 \mathrm{mg}), \mathrm{CH}_{2} \mathrm{Cl}_{2}(350 \mathrm{mg}$ ) and $50 \% \mathrm{CH}_{3} \mathrm{OH} / \mathrm{H}_{2} \mathrm{O}(622 \mathrm{mg})$ fractions. The $\mathrm{CH}_{2} \mathrm{Cl}_{2}$ fraction was then chromatographed with sephadex LH-20 using a 3:1 mixture of $\mathrm{CH}_{3} \mathrm{OH}$ and acetonitrile to give four fractions SF1 (125 mg), SF2 (35 $\mathrm{mg})$, SF3 (90 mg) and SF4 (87 mg). Phytochemical screening using Dragendorff reagent revealed the presence of nitrogenous compounds in fraction 1. This fraction was taken through several rounds of semipreparative HPLC to give $19.0 \mathrm{mg}$ dakaramine, $17.7 \mathrm{mg}$ acetamide and $25.5 \mathrm{mg}$ 1-hydroxypropan-2-yl acetate.

HPLC separation and purification was performed with a Waters 
Citation: Kyeremeh K, Acquah KS, Appiah-Opong R, Jaspars M, Deng H. Effective Detection, Isolation and Characterization of Dakaramine from Ghanaian Axinella sp and Bioactivity. J Chem Applications. 2014;1(1): 4.

1525 Binary HPLC pump chromatograph (Waters) with a 2998 PDA detector, column heater and in-line degasser. Gradients of $\mathrm{H}_{2} \mathrm{O}$ : $\mathrm{MeOH}\left(100 \% \mathrm{H}_{2} \mathrm{O}\right.$ to $100 \% \mathrm{MeOH}$ in 30 minutes and hold for 15 minutes) were used as eluents with flows typically set at $1.5 \mathrm{~mL} / \mathrm{min}$ on a Phenomenex Luna C18 column $(10 \mu \mathrm{m}, 100 \AA$, 150 x $10 \mathrm{~mm}$, Phenomenex).

$600 \mathrm{MHz}{ }^{1} \mathrm{H}$ and ${ }^{13} \mathrm{C}$ NMR spectra were recorded in deuterated chloroform and referenced to the residual solvent signal at $7.26 \mathrm{ppm}$. The system used was a Varian VNMRS $600 \mathrm{MHz}$ NMR spectrometer.

\section{HPLC-ICPMS/ESMS}

The analytical HPLC used was an Accela system from Thermo Scientific (Bremen) consisting of a cooled autosampler with a $100 \mu \mathrm{L}$ sample loop and a column compartment heated to $30^{\circ} \mathrm{C}$. One of the column outlet was connected to a flow split (1:4, Dionex), which in turn was connected to a UV detector (scanning from 200-600 nm, Accela, Thermo Scientific) followed by the ESMS-detector (Orbitrap Discovery, Thermo Scientific). The other split outlet was connected to an ICPMS (Element 2, Thermo Scientific). The column used was a Sunfire C18 $(4.6 \times 150 \mathrm{~mm}$, Waters $)$ with a flow rate of $1 \mathrm{~mL} / \mathrm{min}$. Solvents used were $0.1 \%$ formic acid (Fisher, labgrade) in water (18 $\mathrm{M} \Omega \mathrm{cm}$, Millipore) (solvent A) and $0.1 \%$ formic acid (Fisher, lab grade) in methanol (Fisher, HPLC grade) (solvent B) with a gradient of $0-100 \%$ B within $20 \mathrm{~min}$, hold at $100 \%$ B for $5 \mathrm{~min}$ and reequilibration of the column for $10 \mathrm{~min}$.

The Orbitrap was used with an ESI source, capillary voltage of 4.5 $\mathrm{kV}$ and $320^{\circ} \mathrm{C}$ capillary temperature in positive mode with a resolution of 30.000. $\mathrm{MS}^{2}$ measurement was done using Orbitrap at a resolution of 7500 when the signal intensity was higher than 50,000 counts, and the low resolution iontrap was employed for parallel measuring negative mode. The ICPMS was used in organic mode using platinum cones, $1 \mathrm{~mm}$ injector and a microconcentric nebulizer with $20 \mathrm{~mL} /$ min pure oxygen. All other settings were standard. The instrument was optimised for best sensitivity in low resolution mode. Isotopes measured were ${ }^{69} \mathrm{Ga}$ as internal standard and ${ }^{127} \mathrm{I}$.

\section{Cell culture}

Human lymphocytic (Jurkat) and acute promyelocytic leukemia (HL60) cell lines were obtained from Dr. Takuhiro Uto (Nagasaki International University, Sasebo, Japan). The cells were maintained in RPMI-1640 media (Sigma Aldrich) containing 10\% (v/v) foetal bovine serum (Invitrogen) and $0.01 \%(\mathrm{w} / \mathrm{v})$ kanamycin sulphate (Wako) and incubated at $37^{\circ} \mathrm{C}, 5 \% \mathrm{CO}_{2}$ in humidified atmosphere.

\section{MTT assay}

Cells were seeded at a concentration of $1 \times 10^{5}$ cells per ml into 96 well microtitre plates. Two fold serial dilutions were prepared of the compound dakaramine, with final concentration ranging from $6.25-100 \mu \mathrm{g} / \mathrm{mL}$. The cells were treated with $10 \mu \mathrm{L}$ of the different concentrations of dakaramine. Triplicate experiments were performed for each test concentration. Curcumin (Sigma Aldrich) was used as a positive control, whilst cell culture medium was used as a negative control. Controls (dakaramine in culture medium free of cells) were also included. The microtitre plates were incubated as mention above for $72 \mathrm{~h}$. Subsequently, $20 \mu \mathrm{L}$ of 3-(4,5-dimethylthiazol-2-yl)-2,5diphenyltetrazolium bromide or MTT (Sigma Aldrich) was added to the wells and incubation was continued for $4 \mathrm{~h}$. The reaction was terminated with acidified isopropanol (50 $\mathrm{ml}$ isopropanol containing $170 \mu \mathrm{L}$ of $\mathrm{HCl}$ and $2 \%$ Triton $\mathrm{X}$ ) and the plates were incubated at room temperature $\left(25^{\circ} \mathrm{C}\right)$ in the dark overnight. The optical density of the compound was measured at $570 \mathrm{~nm}$ with a spectrophotometer (Tecan infinite M200PRO model). Percentage cell viability was calculated using the following formula [10]:

$$
\% \text { Cell Viability }=(\mathrm{OD})_{\mathrm{d}}-(\mathrm{OD})_{\mathrm{dc}} /(\mathrm{OD})_{\mathrm{c}}-(\mathrm{OD})_{\mathrm{b}}
$$

where $(\mathrm{OD})_{\mathrm{d}}$ is the optical density of dakaramine treated cells, $(\mathrm{OD})_{\mathrm{dc}}$ is the optical density of wells, test compound and culture media $(\mathrm{OD})_{\mathrm{c}}$ is the optical density of wells containing cells with culture media and $(\mathrm{OD})_{\mathrm{b}}$ is the optical density of wells with only culture media.

\section{Results and Discussion}

Bioaccumulation of metals in marine invertebrates (for example $\mathrm{Cu}, \mathrm{Pb}, \mathrm{Co}, \mathrm{Fe}, \mathrm{Zn}$ ) and the frequent characteristic occurrence of heteroatoms (for example $\mathrm{N}, \mathrm{O}, \mathrm{S}, \mathrm{P}, \mathrm{Cl}, \mathrm{Br}, \mathrm{I}$ ) in many bioactive secondary metabolites are subjects of high interest in our laboratory. Various marine invertebrate extracts are screened on a routine basis using an HPLC-ICPMS/ESMS technique that affords a huge amount of specificity and sensitivity towards these marine derived metabolites. Screening of extracts of Axinella sp revealed the presence of iodinated compounds as shown in Figures 1 and 2, in which the ICPMS and ESMS chromatograms have been overlaid. In Figure 2, it is apparent that, the sponge indeed bioaccumulates iodine within its tissues to facilitate the biosynthesis of iodinated metabolites. The use of HPLC-ICPMS/ESMS led to the isolation of iodinated compound dakaramine. The positive HRESIMS spectrum of $\mathbf{1}$ showed an [M $+\mathrm{H}^{+}$at $\mathrm{m} / \mathrm{z} 503.0040$ corresponding to the molecular formula $\mathrm{C}_{15} \mathrm{H}_{25} \mathrm{I}_{2} \mathrm{~N}_{2} \mathrm{O}^{+} . \delta_{\mathrm{C}}$ at $140.0(2 \mathrm{C})$ and $\delta_{\mathrm{C}} 90.8(2 \mathrm{C})$ assigned to the two aromatic carbons connected to iodine $\left(5,5^{\prime}\right)$ confirmed the presence

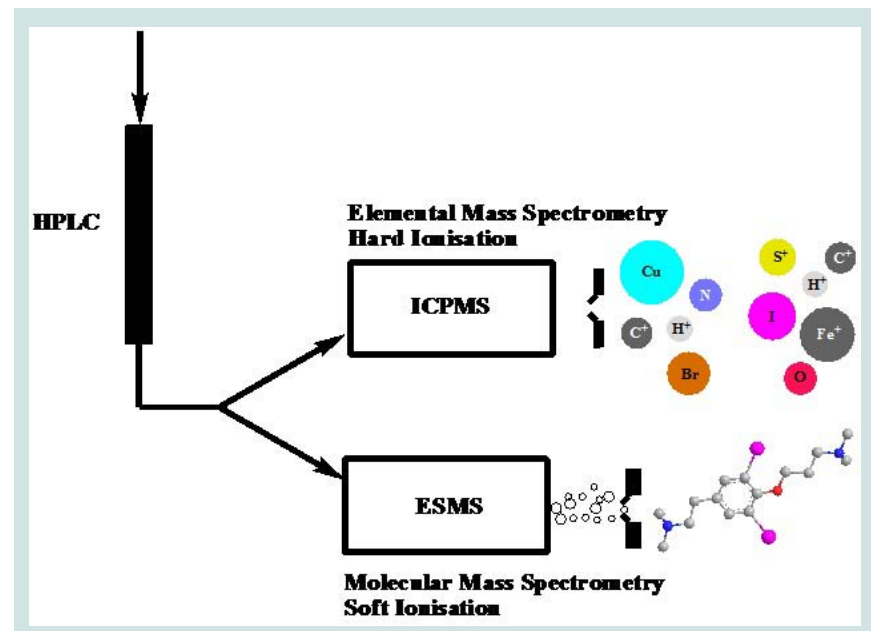

Figure 1: Technique development HPLC-ICPMS/ESMS. Injected samples coming out of HPLC-column is split into two separate lines with one fraction entering an ICPMS and the other an ESMS. While the ionization in ICPMS mode is hard and subsequently takes organic molecule apart, the ionization in the ESMS is soft and designed to give good molecular ions. The chromatogram of the element to be measured (e.g. I, Br, S, As, Cu etc) is extracted from the ICPMS and overlaid with the eluting chromatogram derived from ESMS mode. 
Citation: Kyeremeh K, Acquah KS, Appiah-Opong R, Jaspars M, Deng H. Effective Detection, Isolation and Characterization of Dakaramine from Ghanaian Axinella sp and Bioactivity. J Chem Applications. 2014;1(1): 4.

of a tetra-substituted benzene ring which was definitely symmetrical as seen in the structure of 1 . Two methyl singlets at $\delta_{\mathrm{H}} 2.56\left(\mathrm{~s}, 2 \mathrm{H}_{3}\right)$ and $2.34\left(\mathrm{~s}, 2 \mathrm{H}_{3}\right)$ seen to correlate to their own corresponding $\delta_{\mathrm{c}}$ peaks at 43.7 (2C) and $44.5(2 \mathrm{C})$ respectively in the HMBC spectrum was consistent with the reported structure of 1 . A summary of the 1D and 2D NMR data is given in Table 1 (Scheme 1).

The positive HRESIMS spectrum of compound 2 showed a prominent ion $[\mathrm{M}+\mathrm{H}]^{+}$at $\mathrm{m} / z$ 119.0703, indicating a molecular formula of $\mathrm{C}_{5} \mathrm{H}_{11} \mathrm{O}_{3}{ }^{+}$. The ${ }^{1} \mathrm{H}$ and ${ }^{13} \mathrm{C}$ NMR spectra of $\mathbf{2}$ indicated the presence of an acetyl group $\left(\delta_{\mathrm{H}} 2.00 / \delta_{\mathrm{C}} 22.8, \delta_{\mathrm{C}} 173.1\right)$ and a methyl group $\left(\delta_{\mathrm{H}} 1.14 / \delta_{\mathrm{C}} 18.9\right)$ attached to a $\mathrm{CH}$ group $\left(\delta_{\mathrm{H}} 3.89 / \delta_{\mathrm{C}} 68.4\right)$, which in turn was connected to a primary alcohol function $\left(\delta_{\mathrm{H}} 3.60\right.$, $\left.3.38 \delta_{C} 68.2\right)$. Analysis of the COSY and HMBC spectra established the structure of $\mathbf{2}$ as 1-hydroxypropan-2-yl acetate (specific rotation $=0.0^{\circ}$ for racemic mixture). 2 has repeatedly been described as a synthetic product [11], but to the best of our knowledge has not been isolated as a natural product so far. It should be noted that, this compound was only detected in the present study due to spraying TLC plates with phosphomolybdic acid. A summary of the 1D and 2D NMR data is given in Table 2.

Cytotoxicity of Dakaramine was assessed using two human cancer cell lines, acute promyelocytic leukemia and human lymphocytic cells. The percentage cell viability of both cell lines decreased in a dose dependent manner as shown in Figure 3. Dakaramine inhibited the growth of Jurkat and HL60 cells with $\mathrm{IC}_{50}$ values of 35.0 and $26.5 \mu \mathrm{g} /$ $\mathrm{ml}$ respectively. Curcumin is known to be a potent inhibitor of cancer cell lines and the $\mathrm{IC}_{50}$ values for curcumin in HL60 and jurkat cells were about $2.0 \mu \mathrm{g} / \mathrm{ml}$. Thus, considering the strong cytotoxic activity shown by dakaramine consistently in both cell lines, the compound may serve as a potential anticancer agent. Further investigations are required to establish the anticancer activity and the mechanism of action of Dakaramine.

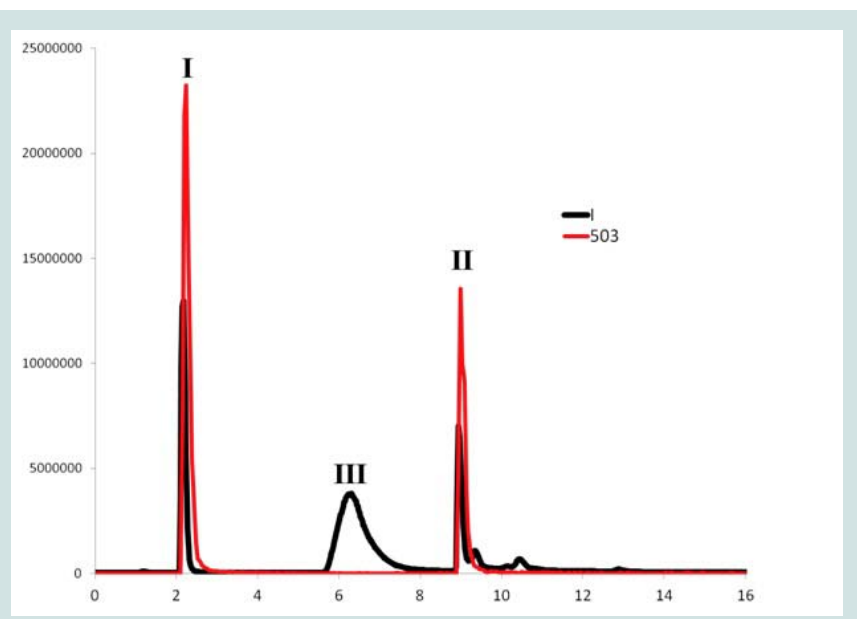

Figure 2: Overlay of ICPMS chromatogram extracted for the element iodine (black line) and ESMS (red line) chromatogram shows the presence of free iodine in the extract (III) and also in the molecular structure of dakaramine (I and II). It is important to note that, the two well resolved peaks I and II separated by column retention time of about 7 minutes have the same UV, MS fragmentation patterns and $1 D$ and 2D NMR data. While these two peaks were seen in the high resolution ESMS of dakaramine and also seen unde certain column conditions in the semi-preparative HPLCs used to isolate dakaramine, it turned out that the two peaks were indeed the same compound (See supplementary material). Also, the big peak (black line) at retention time of about 6.5 minutes (III) shows the presence of free iodine in sample.
Table 1: ${ }^{1} \mathrm{H}$ and ${ }^{13} \mathrm{C}$ NMR spectral data in $\mathrm{CDCl}_{3}$ at $600 \mathrm{MHz}$ for Dakaramine.

\begin{tabular}{|c|c|c|c|c|}
\hline position & ${ }^{13} \mathrm{C}$ & $\begin{array}{c}{ }^{1} \mathrm{H}(\delta / \mathrm{ppm}, \mathrm{m}, \mathrm{J} / \\
\mathrm{Hz})\end{array}$ & cosy & HMBC \\
\hline 1 & $60.0\left(\mathrm{CH}_{2}\right)$ & $2.56(2 \mathrm{H})^{\mathrm{a}}$ & $\mathrm{H}_{2}-2$ & ${ }^{\star} \mathrm{CH}_{3}, \mathrm{H}_{2}-2$ \\
\hline 2 & $31.4\left(\mathrm{CH}_{2}\right)$ & $\begin{array}{c}2.70(2 \mathrm{H}, \mathrm{dd}, 9.6 \\
6.3)\end{array}$ & $\mathrm{H}_{2}-1$ & $\mathrm{H}-4, \mathrm{H}-4^{\prime}$ \\
\hline 3 & 139.5(C) & & & $\mathrm{H}-4, \mathrm{H}-4^{\prime}$ \\
\hline $4,4^{\prime}$ & $140.0(\mathrm{CH})$ & $7.60(2 \mathrm{H}, \mathrm{s})$ & & $\mathrm{H}_{2}-2$ \\
\hline $5,5^{\prime}$ & $90.8(C)$ & & & $\mathrm{H}-4, \mathrm{H}-4$ \\
\hline 6 & $155.7(C)$ & & & $\mathrm{H}-4, \mathrm{H}-4$ \\
\hline 7 & $70.6\left(\mathrm{CH}_{2}\right)$ & $4.02(2 \mathrm{H}, \mathrm{t}, 6.0)$ & $\mathrm{H}_{2}-8$ & \\
\hline 8 & $26.4\left(\mathrm{CH}_{2}\right)$ & $2.27(2 \mathrm{H}, \mathrm{m})$ & $\begin{array}{l}\mathrm{H}_{2}-7 \\
\mathrm{H}_{2}-9\end{array}$ & $\mathrm{H}_{2}-7$ \\
\hline 9 & $55.8\left(\mathrm{CH}_{2}\right)$ & $\begin{array}{c}2.99(2 \mathrm{H}, \mathrm{dd}, 9.7 \\
6.1)\end{array}$ & $\mathrm{H}_{2}-8$ & $\mathrm{H}_{2}-7, \mathrm{CH}_{3}$ \\
\hline $\mathrm{NMe}_{2}-1$ & $44.5\left({ }^{*} \mathrm{CH}_{3}\right)$ & $2.34(6 \mathrm{H}, \mathrm{s})$ & & ${ }^{*} \mathrm{CH}_{3}$ \\
\hline $\mathrm{NMe}_{2}-9$ & $43.7\left(\mathrm{CH}_{3}\right)$ & $2.56(6 \mathrm{H}, \mathrm{s})$ & & $\mathrm{CH}_{3}$ \\
\hline
\end{tabular}

a overlapped
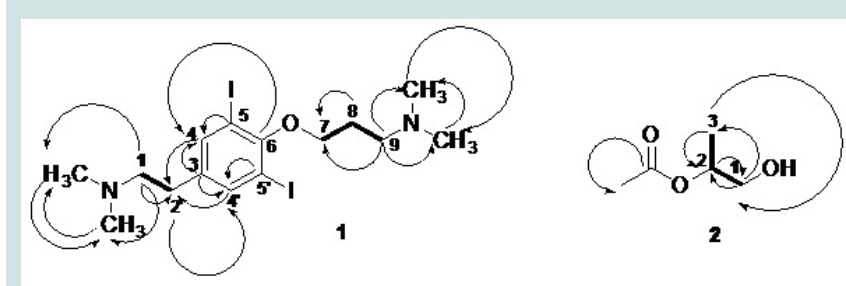

Scheme 1: COSY (bold) and HMBC (arrows, C $\rightarrow \mathrm{H}$ ) correlations for dakaramine and hydroxylated acetate metabolite.

Table 2: ${ }^{1} \mathrm{H}$ and ${ }^{13} \mathrm{C}$ NMR spectral data in $\mathrm{CDCl}_{3}$ at $600 \mathrm{MHz}$ for 1-hydroxypropan2-yl acetate.

\begin{tabular}{|l|c|c|c|c|}
\hline position & ${ }^{13} \mathbf{C}$ & ${ }^{1} \mathbf{H}(\delta / \mathbf{p p m}, \mathbf{m}, \mathbf{J} / \mathrm{Hz})$ & $\mathbf{C O S Y}$ & $\mathbf{H M B C}$ \\
\hline $1,1^{\prime}$ & $68.2\left(\mathrm{CH}_{2}\right)$ & $\begin{array}{c}3.60(1 \mathrm{H}, \mathrm{dd}, 11.1,3.0) \\
3.38(1 \mathrm{H}, \mathrm{dd}, 11.1,7.8)\end{array}$ & $\begin{array}{c}\mathrm{H}-1 \\
\mathrm{H}-1^{\prime}\end{array}$ & $\begin{array}{c}\mathrm{H}_{3}-3 \\
\mathrm{H}-2\end{array}$ \\
\hline 2 & $68.4(\mathrm{CH})$ & $3.89(1 \mathrm{H}, \mathrm{dqd}, 7.8,6.4,3.0)$ & $\begin{array}{c}\mathrm{H}_{3}-3 \\
\mathrm{H}_{2}-1 \\
\mathrm{H}_{2}-1^{\prime}\end{array}$ & $\mathrm{H}-1^{\prime}$ \\
\hline 3 & $18.9\left(\mathrm{CH}_{3}\right)$ & $1.14(3 \mathrm{H}, \mathrm{d}, 6.4)$ & & $\mathrm{H}-2, \mathrm{H}-1, \mathrm{H}-1^{\prime}$ \\
\hline 4 & $173.1(\mathrm{C})$ & & & $\mathrm{H}_{3}-5$ \\
\hline 5 & $22.8\left(\mathrm{CH}_{3}\right)$ & $2.00(3 \mathrm{H}, \mathrm{s})$ & & \\
\hline
\end{tabular}

\section{Conclusions}

The current research is a direct attestation to the apparent widespread occurrence of iodotyramine derivatives across different Phyla of marine organisms. It also provides the first report of in vitro toxicity to two human cancer cell lines for dakaramine a very important member of this class of alkaloids. Using this case as an example, the current research has introduced an innovative HPLCICPMS/ESMS methodology developed and routinely used to assist the screening of metals and heteroatoms in marine invertebrates or microbial extracts. The data obtained clearly shows that, iodine is bioaccumulated in the tissues of the organism to facilitate the biosynthesis of these Iodotyramine derivatives. A new hydroxylated acetate metabolite is also reported and even though this metabolite is not structurally intriguing, it is possible that it might have something 
Citation: Kyeremeh K, Acquah KS, Appiah-Opong R, Jaspars M, Deng H. Effective Detection, Isolation and Characterization of Dakaramine from Ghanaian Axinella sp and Bioactivity. J Chem Applications. 2014;1(1): 4.

A)

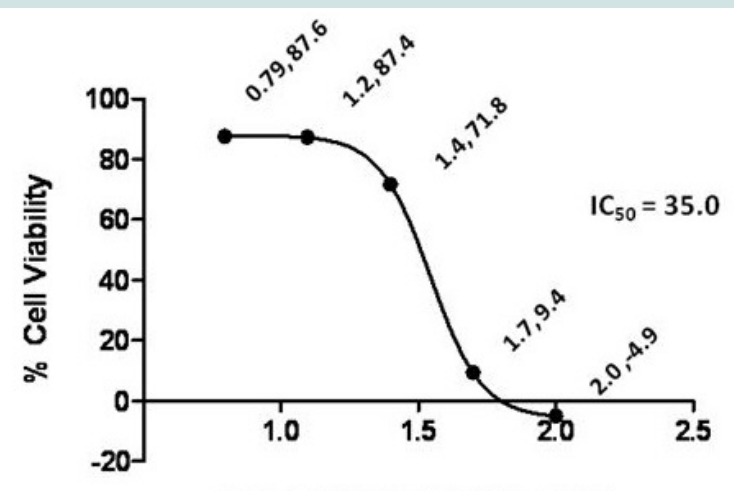

Log [Dakaramine (1)] $\mu \mathrm{g} / \mathrm{ml}$

B)

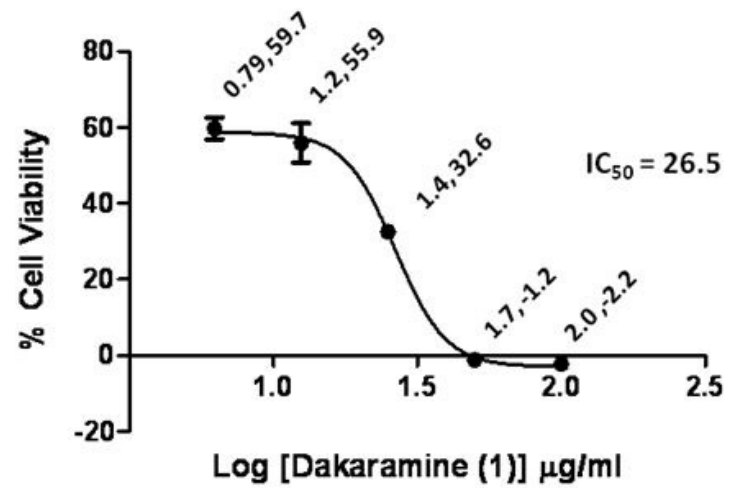

Figure 3: Cytotoxicity of dakaramine (A) towards Jurkat cells; (B) towards HL60 cells. The figures represent mean values and standard deviations of triplicate experiments. to do with the biosynthesis of some secondary metabolites in this sponge.

\section{References}

1. Blunt J, Murray M (1970) MarinLit database, Department of Chemistry, University of Canterbury, New Zealand.

2. Constantino V, Fattorusso E, Mangoni A, Pansini M (1994) Three new brominated and iodinated tyrosine derivatives from lotrochota birotulata, a non-Verongida sponge. J Nat Prod 57: 1552-1556.

3. Diop M, Samb A, Constantino V, Fattorusso E, Mangoni A (1996) A new iodinated metabolite and a new alkyl sulfate from the Senegalese sponge Ptilocaulis spiculifer. J Nat Prod 59: 271-272.

4. Kigoshi H, Kanematsu K, Uemura D (1999) Turbotoxins A and B, novel diiodotyramine derivatives from the Japanese gastropod Turbo marmorata. Tetrahedron Letters 40: 5745-5748.

5. Kigoshi H, Kanematsu K, Yokota K, Uemura D (2000) Turbotoxins A and $B$, novel diiodotyramine derivatives from the Japanese gastropod Turbo marmorata. Tetrahedron 56: 9063-9070.

6. Solano G, Motti CA, Jaspars M (2009) New iodotyramine derivatives from Didemnum rubeum. Tetrahedron 65: 7482-7486.

7. Heyland A, Moroz LL (2005) Cross-kingdom hormonal signaling: an insight from thyroid hormone functions in marine larvae. J Exp Biol 208: 4355-4361.

8. Murphy CD (2003) New frontiers in biological halogenations. J Appl Microbiol 94: 539-548.

9. Carrol AR, Bowden BF, Coll JC (1993) Studies of Australian Ascidians. II. Novel Cytotoxic lodotyrosine-Based Alkaloids From Colonial Ascidians, Aplidium sp. Aust J Chem 46: 825-832.

10. Ayisi NK, Appiah-Opong R, Gyan B, Bugyei K, Ekuban F (2011) Plasmodium falciparum: Assessment of selectivity of action of chloroquine, Alchornea cordifolia, Ficus polita, and other drugs by a tetrazolium-based colorimetric assay. Malar Res Treat 2011: 1-7.

11. Cotterill AS, Gill M, Milanovic NM (1995) Pigments of fungi. Part 41. Synthesis of $(S)-(+)$ - and (k)-dermolactone; stereochemistry of dermolactone from the Australian fungus Dermocybe sanguinea (Wulf. ex Fr.) Wunsche sensu Cleland. J Chem Soc Perkin 1: 1215-1223.

\section{Acknowledgements}

The authors are extremely grateful to the Royal Society-Leverhulme Trust (AA090088) for providing funds for this project which involves detailed investigation of Ghanaian terrestrial and marine secondary metabolites. The University of Ghana Research Fund provided seed-funding which enabled initial collections of the invertebrates. We are also thankful to Professor Robert van Soest for providing insights into the taxonomy of most of the sponge materials collected. 